\title{
Multisensory Model: Implementation and Contribution of Home Early Literacy Stimulation
}

\author{
Lisnawati Ruhaena ${ }^{1} \mathcal{E}$ Moordiningsih $^{2}$ \\ ${ }^{1}$ Faculty of Psychology, Universitas Muhammadiyah Surakarta \\ ${ }^{2}$ PKU Muhammadiyah Surakarta Hospital
}

\begin{abstract}
A multisensory model was implemented to improve stimulation and development of early literacy skill. This implementation was conducted on 56 mothers and their children aged 3-5 years old, by giving them literacy media and assistance to the mothers. The assistance was carried out by 21 literacy ambassadors. Each literacy ambassador helped 2-3 mothers. Mixed Method Action Research (MMAR) was conducted to implement multisensory model and evaluate its contribution. Quantitative data were collected by scales, while qualitative data were collected by observation, interviews, and questionnaires. Quantitative data analysis was done with Paired Sample T-Test, and qualitative data analysis was conducted with content analysis. Once the multisensory model was applied, the stimulation of children's literacy shifted from a textual way to a contextual way. Multisensory models contributed to creating a storybook reading routine and playing hand puppets, letter cards, and activity books. This contribution was very important because it significantly increased the literacy activity and developed children's literacy skill.
\end{abstract}

Keywords: early childhood; early literacy; multisensory models

Nowadays, the development of digital technology has expanded rapidly and the flow of information has become extremely massive that it is becoming easier to have access of information due to internet. The development compels people to skillfully absorb and process information existing in various media. The rapid development of information technology also influences all individuals including children of early age. Children are introduced to smartphone in addition to television and laptop. As the result, they are exposed to words and letters earlier than their age, even though they do not have the understanding of the written words. Unfortunately, children are not

\footnotetext{
${ }^{1}$ Address for corespondence: lisnawati.ruhaena@ums.ac.id, moordiningsih@gmail.com
}

encouraged to practice their skills in absorbing written information. Moreover, parents and teachers are indecisive about the right time and ways for them to stimulate early literacy skills.

A preliminary study carried out by the authors, in 2017 showed that most parents believe that the children's literacy skills were taught later in Kindergarten or Elementary School hence they tend to ignore early literacy stimulation at home. Likewise, the teachers of kindergarten are relatively confused whether children should be taught to read and write since the government does not recommend reading and writing as compulsory subject. In fact, most parents urge teachers to generate graduates with high literacy skills. The problematic issue about early literacy stimulation becomes a serious 
concern of the present study. It relates to the strategic positions of parents and teachers as educators at home and school, particularly to develop children's literacy skills at their golden age. Knowledge and skills are required so that they can play an optimal role in fostering the nation's future generation. The theoretical and empirical study was conducted as an attempt to solve this issue.

Recent theoretical studies show a shift from reading readiness to emergent literacy approach. It means that there is a shift in the notion of stimulating literacy when children are six years old and above towards early age stimulation. The stimulating shift from Elementary School learning towards meaningful daily lives and contextual activities in family literacy. Nevertheless, this shift of approach has not been fully felt and experienced by parents and teachers in Indonesia. Thus, this paper attempts to provide enlightenment, especially focusing on children early literacy stimulation by parents at home.

Family is considered as potential asset in the process of early literacy stimulation (Anderson, Anderson, Friedrich, \& Kim, 2010), therefore, the practice of early childhood literacy can be done appropriately with family. Study on the early literacy stimulation through a movie entitled "Jalan Sesama" was conducted in Pandeglang, Indonesia, showed that proper stimulation could effectively improve children's literacy skills (Borzekowski \& Henry, 2011). Such stimulation could be performed using various media in our surrounding and does not necessarily require high cost media. Furthermore, any texts scattered around the house can be used as media, for example logos, labels, street names, and shop names (Neumann, Hood, \&
Ford, 2013; Neumann, Hood, Ford, \& Neumann, 2012).

Children early literacy stimulation can be initiated by parents at home as a family literacy activity. According to Brooker (2011), the stimulation should be in enjoyable playing activities. This is due to the nature of playing as children's needs. Playing is a fun activity for children hence learning through playing will not be a burden. Parents can try letters and words games (Stephenson, Parrila, Georgiou, \& Kirby, 2008), give children verbal scaffolding while reading stories (Neumann \& Neumann, 2009), or do role playing (Roskos, Christie, Widman, \& Holding, 2010). Interactive reading books, according to DeBruin-Parecki (2009), is an important phase in early literacy stimulation. Literacy activity carried out on a regular basis will have huge impact on children. In families with stable condition, parents tend to carry out early literacy stimulation through joint literacy activities between parents and children (Weigel, Martin, \& Bennett, 2010).

According to constructivist theory of Piaget (Santrock, 2017), literacy skills are achieved by children through active process of understanding a text. Cognitive constructivist theory reviewed the achievement of child literacy as an individual process, which occurs within children's internal mind since they have the capacity to understand their environment. Meanwhile, social constructivist theory of Vygotsky (Santrock, 2017), reviewed the achievement of literacy skills as a social process because children receive stimuli and opportunities to interact with their social environment, especially with the presence of other people who are more competent. 
Ruhaena (2008) unveiled the effectiveness of multisensory learning method for pre-school since it can be adjusted to children's needs and psychological characteristics. This approach creates fun learning while playing that optimizes all children's sensory senses (audio, visual, and kinesthetic senses). It offers a proper solution in relation to early literacy stimulation.

Multisensory model is an integrated early literacy stimulation initiated at home by parents in a fun, playful situation while stimulating children's senses at once. Ruhaena (2015) affirmed that in this model, parents have strategic role as educators, playing activities have a strategic learning process, and literacy is basic learning subject, then multisensory approach is an effective learning method. Ruhaena (2015) design a multisensory model to stimulate literacy in preschoolers. It is important to understand the implementation of multisensory model, especially within family environment. Therefore, this research was conducted.

Multisensory model is designed as early literacy stimulation that targets the development of children's literacy skills by empowering mothers to carry out literacy activities with their children. For this reason, the mothers receive training to increase their knowledge about multisensory method for early literacy stimulation. In addition, the supporting media in literacy activities are also provided in a package (Ruhaena, 2015).

Numerous studies have discussed early childhood literacy, including Altun and Sar1 (2018); Silvers, Shorey, and Crafton (2010); Buvaneswari and Padakannaya (2017); Baker (2013); Fern and Jiar (2013); Greene and Serro (2015); Friesen and Butera (2015); Powers, Wang,
Beach, Sideridis, and Gaab (2016); van Steensel, McElvaney, Kurvers, and Herppich (2011); Reyes and Torres (2007); Zygouris-coe (2007); Hatherly and Chapman (2013); Flewitt, Messer, and Kucirkova (2015); Lonigan and Shanahan (2010); Barratt-Pugh and Maloney (2015); Van der Schuit, Peeters, Segers, van Balkom, and Verhoeven (2009); Newland, Gapp, Jacobs, Reisetter, Syed, and Wu (2011); Neumann, Hood, and Neumann (2009); Neumann and Neumann (2009); Roskos et al. (2010); Stephenson et al. (2008); Weigel et al. (2010); and Anderson et al. (2010).

Altun and Sari (2018) conducted study on early literacy and classified the collected data; Silvers et al. (2010) focused on the perspective of literacy practice on students; Buvaneswari and Padakannaya (2017) constructed questionnaire on the development of home environment in literacy development; Baker (2013) investigated the implication of literacy improvement program at home and its influence on the development of children's emotion; Fern and Jiar (2013) discussed the development of child literacy in families using various languages; Greene and Serro (2015) revealed the empowerment of thinking and reading process with Literacy Bags; Friesen and Butera (2015) found family tradition of literacy-related activities influenced children's literacy development; Powers et al. (2016) examined the relationship between literacy at home and phonological development of beginner readers in families at risk for dyslexia and normal families; van Steensel et al. (2011) examined the effectiveness of literacy programs in the family using meta-analysis; Reyes and Torres (2007) reconstructed the role of families as child literacy educators; Zygorius-Coe (2007) tried to connect literacy activities at home 
and at school; Hatherly and Chapman (2013) examined the use of iPad towards fostering literacy motivation in early childhood education; Flewitt et al. (2014) found the literacy activities content of iPad can help the development of literacy and concentration in children; Barratt-Pugh and Maloney (2015) evaluated literacy improvement program in early childhood; Lonigan and Shanahan (2010) tried to identify popular as well as incomprehensible literacy activities among the community; van der Schuit, et al. (2009) examined the role of home environment on the development of early literacy with intellectual impairments; Newland, et al. (2011) examined the role of mother's trust in literacy activities and children's literacy skills; Neumann and Neumann (2009) examined the improvement of literacy skills; Roskos et al. (2010) investigated literacy games using meta-analysis method; Stephenson, et al. (2008) examined the effects of literacy at home, parents' beliefs, and assignments to children on literacy skills and reading words; Weigel, et al. (2010) examined the relationship between families and literacy skills in preschool children; and Anderson, et al. (2010) examined various perspectives on literacy at home.

Studies on multisensory have also been carried out by several researchers, including Ruhaena (2015); Fitri (2018); Sejati and Yumpi-R (2016); Basam and Sulfasyah (2018); and Praptiningrum and Purwandari (2009). Ruhaena (2015) found multisensory models as a solution for early literacy stimulation; Fitri (2018) examined the development of multisensory model in early childhood with special needs; Sejati and Yumpi-R (2016) disclosed the influence of multisensory method on the ability to remember the alphabet; Basam and Sulfasyah (2018) studied the multisensory VAKT learning method as an effort to improve the reading skills of class II students; and Praptiningrum and Purwandari (2009) examined multisensory method for developing the reading skills of dyslexic children in inclusive elementary schools.

The present study is different from previous studies on early literacy and multisensory method that have been carried out previously. First, the present study was conducted in Surakarta in which multisensory model for literacy stimulation had never been applied in any school. Second, this study used MixedMethod Action Research method. Third, the approach of multisensory model integrated media, tools, and technique in a holistic manner.

\section{Method}

The present study used a Mixed Method Action Research (MMAR) which aimed at implementing a multisensory model in early childhood literacy stimulation and evaluating it on the basis of quantitative and qualitative data. Furthermore, it attempted to obtain comprehensive empirical evidence by conducting statistical analysis and content analysis. Statistical analysis used to test the significance differences in pre-test and post-test score, while content analysis used to describe the dynamics that occur in the stimulation process.

The participants of this study were 56 women whose children aged 3-5 years old. They lived in Surakarta, Central Java, Indonesia. They aged between 25-45 years old, with educational background from high school to higher education. They were employees in private companies, teachers, entrepreneurs, and housewives. Both mother and children 
received assistance from the ambassador of literacy. Each ambassador assisted two or three dyad mother-children. There were 21 ambassadors selected from Bachelor's Degree students of Faculty of Psychology, Universitas Muhammadiyah Surakarta with certain criteria, namely passed the observation and interview exam and expressed willingness to participate by filling the informed consent. The participants joined the research after the literacy ambassador gave them explanation about the literacy program set in the present study and stated their participation by signing the informed consent.

The present study focused on the application of multisensory model and its contributions in early literacy stimulation. The research questions were: a) How is the way of early literacy stimulation at home before the implementation of multisensory model?; b) How to stimulate children at home using multisensory models?; c) How is the contribution of multisensory model on early literacy stimulation?

The multisensory model was implemented in the form of literacy programs which enabled mothers to implement family literacy so that children are exposed to more early literacy activities at home. Prior to the implementation of literacy programs, a need assessment was done. It aimed to obtain an overview of general literacy stimulation and the needs to be fulfilled in program implementation. Subsequently, the program was implemented in three cycles in which the evaluation of the first cycle used as an improvement for the second cycle while the evaluation of the second cycle used to improve the third cycle. These cycles were reading story books, playing, and activity books. Each cycle involved the stages of planning, implementation, observation, and reflection. Planning intended to prepare the activities and media; implementation was the process of visiting literacy ambassador for assistance; observations were performed by the literacy ambassador during the visit; and reflection was done to gain insight to make further planning. The cycles are summarized in Figure 1.

Quantitative data were collected by scale, while qualitative data were collected by open questionnaires, in-depth interviews, and observations. The scales were divided into the scale of early literacy skills, the scale of literacy activities, and the scale of mother's knowledge. This scales were used at both pretest and posttest stages. Open questionnaires were used to collect data on the needs and

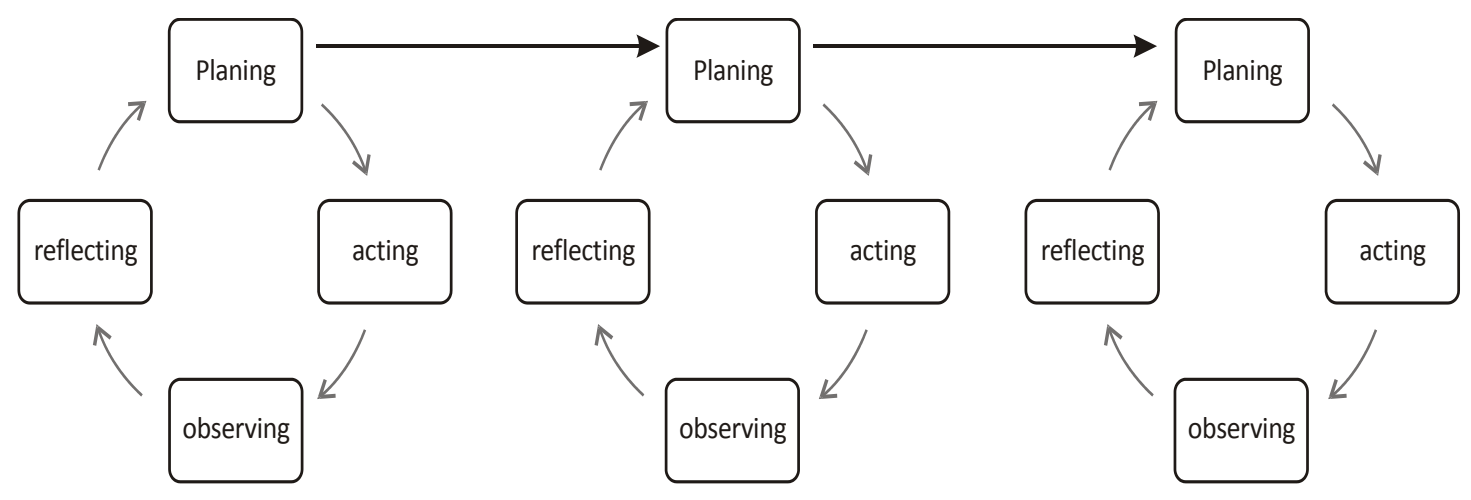

Figure 1. The action research with three cycles 
processes of literacy activities at home. Observations and in-depth interviews were used to reveal interactions between mothers and children during literacy activities, and to understand their responses toward the activities on each cycle.

\section{Result}

The answer to the first research question about early literacy stimulation at home, was obtained from need assessment. Its results showed that: first, $68 \%$ of participants had interactive conversations with children during their play activities, while $32 \%$ of participants tended to be passive and supervise their children. It implied that the majority of mothers had a willingness to actively provide direction and stimulate their children. Second, 55\% of participants accompanied their children to train fine motor skills, $34 \%$ accompanied their children in literacy activity, while $11 \%$ were not involved in any play activities. It implied that fine motor activities were preferred than literacy activities. Third, 32\% of participants never read story books, 34\% rarely/infrequently read story books before going to bed, while 34\% told stories and recited dua and Quranic verses. It implied reading a story book had not become a habit. Fourth, $50 \%$ of participants taught textual reading and writing (with syllable spelling exercise books), 33\% provided stationery, posters, spectacles, while $17 \%$ invited their children to play in recognizing letters. It showed that the methods used by mothers to stimulate children's literacy were less meaningful and less interesting in a contextual way.

To sum up, the data obtained from the needs assessment showed that most mothers had actively conducted children literacy stimulation through interactive conversation and fine motor activities. However, they had not been accustomed to read story books on a regular basis, but preferred teaching children to read and write textually and providing equipment for such activities. Thus, contextual literacy stimulation by inviting children to perform purposeful and meaningful activities, such as reading story books, should be promoted.

The second research question was how multisensory model implemented to optimize early literacy stimulation at home in order to increase early literacy skills. The data of early literacy skills are presented in Table 1.

The analysis of children's literacy skills showed that there was a significant increase from the mean of 27.0 (moderate)

Tabel 1.

Quantitative Data

\begin{tabular}{lllllll}
\hline Quantitative Data & \multicolumn{2}{l}{ Children's Literacy Skills } & \multicolumn{2}{l}{ Literacy Activities } & \multicolumn{2}{l}{ Mother's Knowledge } \\
\hline $\mathrm{N}=50$ & Pre & Post & Pre & Post & Pre & Post \\
$\mathrm{SD}$ & 8.48 & 7.97 & 14.5 & 13.0 & 3.6 & 4.5 \\
Mean & 27.0 & 35.8 & 57.3 & 62.8 & 17.1 & 17.3 \\
Category & Moderate & High & Moderate & High & Moderate & Moderate \\
Normality Test & Normal & Normal & Normal & Normal & Normal & Normal \\
\hline t Test Difference & \multicolumn{2}{r}{$\mathrm{t}=-9.54, \mathrm{p}=0.000}$, & $\mathrm{t}=-3.136, \mathrm{p}=0.003$, & $\mathrm{t}=-0.432, \mathrm{p}=0.668$ \\
& \multicolumn{3}{r}{ (Significant) } & (Significant) & (Insignificant) \\
\hline
\end{tabular}


before the implementation of multisensory model to 35.8 (high) after the implementation. Similarly, for literacy activities, there was a significant increase from 57.3 to 62.8 . Nevertheless, there was insignificant difference for the mothers' knowledge, from 17.1 to 17.3 and still in the moderate category.

The multisensory model was implemented with the assistance from literacy ambassadors and provision of literacy media. Furthermore, qualitative data were collected from in-depth interviews with the participants, and observations on children related to the literacy stimulation process.

The results of in-depth interviews and observations indicated that with assistance and provision of literacy media, mothers and children could carry out literacy activities. The mothers began literacy activities by inviting children and exemplifying the activity. Literacy activities were carried out at least once a day, by performing at least one type of literacy activity. Children showed positive response toward literacy media. They also showed an enthusiastic response during storytelling and interactive during letter card game. However, some mothers still faced the shortcomings, such as children were easily bored, lack of concentration, and become tired quickly in performing literacy activities.

\section{Discussion}

Based on analysis of quantitative and qualitative data, the implementation of multisensory models was able to optimize early literacy stimulation. It had been shown by the significant increase in literacy activities and children's literacy skills. Qualitatively, the children would actively, interactively, enthusiast, and cheerfully participate in literacy activities.

Tabel 2.

Qualitative Data

\section{Interview}

Observation

Out of 56 children,

- Majority of them (91\%) perform at least one literacy activity.

- Majority of them (94\%) like the provided literacy media.

Out of 56 mothers,

- Majority of them (85\%) begin literacy activities by inviting their children and exemplifying.

- Majority of the mothers (91\%) do at least one activity in a day.

- Majority of them (92\%) mention the difficulties during the process, including children are more likely to get bored easily, lack of $\bullet$ concentration, and easy to get tired.
Children's responses:

- Majority of children (85\%) show enthusiasm when their mothers encourage them to join the literacy activity.

- Majority of children (80\%) show active respond when their mothers read story book.

- Majority of children (84\%) show calm behavior and actively ask their mothers during storytelling.

Majority of children (87\%) show interactive behavior towards their mothers during storytelling.

- Majority of children (91\%) show interactive respond while playing letter cards.

Majority of children (75\%) show enthusiasm when drawing. 
Such activities were also performed regularly, at least once a day. However, the implementation of multisensory model had not significantly improved the mothers' knowledge about literacy stimulation. The problems were related to children's lack of concentration, as well as dullness and exhaustion. Most mothers had not noticed the disposition of early childhood development in which children can only concentrate for certain period.

The contribution and benefits of multisensory model in early literacy stimulation had been reported. The implementation of this model allows parents to utilize various approaches, methods, materials, and media in stimulating children's literacy potential. With assistance and the provision of literacy media, mothers began to use proper approach to stimulate child literacy in a contextual manner, through story books, letter cards, and activity books. It differed from previous approach, which was to teach children in a more textual manner such as by training children to spell and dictate syllables without meaning (for example: ba, bi, bu, be, bo). The method was playing while learning, which was more interesting and appropriate for the children. The activities involved story books (reading, storytelling, discussion), letter cards (arranging letters into words, manipulating the arrangement of letters to change words), and activity books (coloring, lining, drawing). The stimulation was done by introducing and fostering literacy interest, instead of memorizing letters and spelling words. Various media, including story books, hand puppets, picture books, markers, letter cards, activity books, and colored pencils were employed to attract children's attention and facilitate fun literacy activities to raise children's interest in reading. It differed from previous approach that merely covers reading exercises book (abaca), writing materials, and notebooks.

With assistance and provision of literacy media, the mothers could invite and exemplify literacy activities for their children. Their active involvement in literacy activities would build their knowledge. Through attractive and fun literacy media, children would experience learning while playing, instead of learning under burden or pressure. It gave children the opportunity to have a constructive learning in which children became subjects who built their own knowledge. Happiness and enthusiasm felt by children could also develop children's interest in literacy activities. The growing interest would motivate children to use media and perform similar activities, and as the result, a literacy routine could develop into a habit and a culture of literacy.

The present study aimed at implementing the multisensory model and evaluating its contribution to early literacy stimulation at home. After the implementation of multisensory model, the early literacy stimulation became more optimal. Quantitatively, there was a significant increase in literacy activities and children's literacy skills. Qualitatively, children had enjoyable learning experience and interest in literacy. Thus, the implementation of multisensory model contributed to the emergence of contextual approach to literacy stimulation, playing while learning method, meaningful material, and varied media.

In this discussion, a constructivist theory was applied to review research findings. Then, it was described how multisensory model contribute to optimizing early literacy stimulation. 
Constructivists theory was chosen as Piaget and Vygotsky perceived individuals or children as subjects who actively built and constructed their own knowledge and understanding (Karpov, 2005; Santrock, 2017).

The early literacy stimulation at home could be optimized with multisensory model. It situated children to receive stimuli and opportunities through their involvement in literacy activities that eventually improved their literacy skills. The stimulants were in the forms of interesting stuffs, for example fairy tales books, card, toys and dolls. Furthermore, parents or mothers could employ a contextual approach, i.e., game and fun media to raise children's interest.

According to constructivist theories, the achievement of early literacy could be viewed as an individual and social process. This process was seen as the result of individual interactions with the social environment. It meant that such skills were attained due to social interaction between children and those who had ability and knowledge. In a review of Vygotsky's concept, mothers provided verbal guidance to develop children's actual abilities (zone of proximal). With assistance, mothers guided literacy activities more systematically and invited children to actively participate in literacy-related social interactions, such as reading books, playing letter cards, and coloring. During child-mother interaction, there was a transfer of knowledge that can be continued regularly and eventually it forms a habit.

Meanwhile, based on Urie Brofenbrenner's ecological theory (Santrock, 2017), mother was a part of child's micro system. It implied that when mother played her roles as a companion to stimulate children, it would have positive impact on children's literacy skills. Moreover, the outcome would be more optimal when mother used concrete examples or multisensory models with various media. Jean Piaget (Neaum \& Tallack, 2000) argued that children in the phase of a preoperational style of thinking would easily capture messages conveyed by mothers through multisensory model. This model entailed mother's commitment and creativity to assist and provide concrete examples in literacy activities. Previous researches also showed the significant role of mothers and community in children development. It included van der Schuitt et al. (2009) on the influence of surrounding community in the development of preschoolers with intellectual impairments; Newland, et al. (2011) on the role of mothers to increase children's literacy activities and skills; and Friesen and Butera (2015) about the effect of literacy-related family activities on children's literacy development.

An integration of individual and social constructivist theory explained that early literacy skills were the outcome of child's understanding process towards texts as well as in interacting and communicating with the social environment. Learning process occurred in their daily interaction and meaningful activities based on respective social context. Furthermore, parents acted as facilitators who should encourage and guide structured activities, adjusted to children's abilities and needs. Thus, children were directed and facilitated to achieve higher literacy skills without ignoring their interests, basic potential, and orientation.

Even though children were born with basic potentials of attention, sensation, perception and memory, these potentials 
will develop through socio-cultural interaction that eventually leads to a more mature mentality. Therefore, despite cognitive processes occured at individual level, they are still influenced by external stimulation, especially mother. Corsaro and Nelson (2003) also supported the notion that children are individuals who have curiosity and are actively involved in their own learning process to build understanding or scheme, yet this process still requires social interaction.

The role of external stimulation allows mothers or parents to use various facilities for optimizing children's sensory and motor skills. This condition was shown by Flewitt et al. (2014) who found that literacy-related contents in iPad can be useful in children's development of literacy and concentration. Likewise, the present study also used various facilities and involved the optimization of children's sensory and motor skills. This study implemented multisensory techniques or models, namely literacy stimulation models that utilized various items, i.e., dolls, writing books, coloring books, fairy tales books, and so on. Therefore, when compared with Flewitt et al. (2014) who only used iPad, the model developed in the present study was more effective in improving children's literacy and motor skills. Neumann and Neumann (2009), Neumann, Hood, and Neumann (2009), Neumann et al. (2013), and Neumann, Hood, Ford, and Neumann (2012) also argued that various facilities can be combined as early literacy stimulation.

\section{Conclusion}

The implementation of multisensory model supported early literacy stimulation at home. Quantitatively, there was a significant increase in literacy activities and children's literacy skills. Qualitatively, children experienced a more enjoyable learning process that enhanced their interest in literacy. The optimization of early literacy stimulation at home could occur because multisensory model allows children to receive stimuli and have opportunities to be actively involved in literacy activities that ultimately improve their skills. Furthermore, it promoted contextual approach that facilitated the utilization of interesting media to attract children's interest. In overall, multisensory model shifted the early literacy stimulation from a textual to a contextual way.

The multisensory model contributed to the emergence of a more contextual approach to literacy stimulation, for example the methods of playing while learning, meaningful material, and various media. It was seen as conducive method to promote regular literacy activities. It was very important because it could be a solution to the problematic issues related to the appropriate stimulation method for fostering literacy interest.

\section{Recommendation}

Multisensory model should be applied as an intervention to improve children early literacy and home literacy activities in Indonesian family. To do so, mothers need to receive training about how to do early literacy stimulation in multisensory model. The systematic action or movement needs to be done by optimizing parents training in community based informal education. Moreover, the more suitable training needs to be designed and applied in order to increase parents knowledge about early literacy stimulation. 


\section{References}

Altun, D., \& Sarı, B. (2018). A decade of early literacy research trends in Turkey: $A$ thematic review, (April 2017), 13-32. Retrieved from http://dergipark.gov.tr/download/artic le-file/419951

Anderson, J., Anderson, A., Friedrich, N., \& Kim, J. E. (2010). Taking stock of family literacy: Some contemporary perspectives. Journal of Early Childhood Literacy, 10(1), 33-53.

Baker, C. (2013). Fathers' and mothers' home literacy involvement and children's cognitive and social emotional development: Implications for family literacy programs. Applied Developmental Science, 17(4), 184-197.

Barratt-Pugh, C., \& Maloney, C. (2015). Growing better beginnings: An evaluation of a family literacy program for pre-schoolers. Issues in Educational Research, 25(4), 364-380.

Basam, F., \& Sulfasyah. (2018). Metode pembelajaran multisensori VAKT sebagai upaya meningkatkan kemampuan membaca lancar siswa kelas II. Jurnal Riset Pendidikan Dasar, 1(1), 1824.

Borzekowski, D. L.; \& Henry, H. K. (2011). The impact of jalan sesama on the educational and healthy developmet of indonesian preschool children: An experimental study. International Journal of Behavioral Development, 35(2), 169-179.

Brooker, L. (2011). Taking children seriously: an alternative agenda for research? Journal of Early Childhood Research, 9(2), 137-149

Buvaneswari, B., \& Padakannaya, P. (2017). Development of a home literacy environment questionnaire for
Tamil-speaking kindergarten children. Language Testing in Asia, 7(1), 14. doi: $\underline{10.1186 / s 40468-017-0047-y}$

Corsaro, W. A., \& Nelson, E. (2003). Children's collective activities and peer culture in early literacy in American and Italian preschools. Sociology of Education, 76, 209-227.

DeBruin-Parecki, A. (2009). Establising a family literacy program with a focus on interactive reading: The role of research and accountability. Early Childhood Education Journal, 36(5), 385392.

Fern, N. P., \& Jiar, Y. K. (2013). Emergent literacy in a print-rich multilingual home environment. International Journal of Humanities and Social Science, 3(13), 146-155.

Fitri, N. L. (2018). Pengembangan literasi multisensori pada anak usia dini berkebutuhan khusus. Al Hikmah Proceedings on Islamic Early Childhood Education, 1, 503-512.

Flewitt, R., Messer, D., \& Kucirkova, N. (2015). New directions for early literacy in a digital age: The iPad. Journal of Early Childhood Literacy, 15(3), 289-310. doi: 10.1177/1468 $\underline{798414533560}$

Friesen, A., \& Butera, G. (2015). “You introduce all of the alphabet but I do not think it should be the main focus": Exploring early educators' decision about reading instruction. Early Childhood Education Journal, 20, 361368.

Greene, J., \& Serro, L. C. (2015). Encouraging critical thinking and professional reading with literacy bags. The Open Communication Journal, 9(1), 65-71. doi: 10.2174/1874916X $\underline{01509010065}$

Hatherly, A., \& Chapman, B. (2013). 
Fostering motivation for literacy in early childhood education using iPads. Computers in New Zealand Schools: Learning, Teaching, Technology, 25(1-3), 138-151.

Karpov, Y. V. (2005). The Neo-Vygotskian approach to child development. New York, NY: Cambridge University Press.

Lonigan, C. J.; \& Shanahan, T. (2010). Developing early literacy skills: Things we know we know and things we know we don't know. Educational Researcher, 39(4), 340-346. doi: $\underline{10.3102 / 0013189 \times 10369832}$

Neaum, S., \& Tallack, J. (2000). Good practice in implementing the pre-school curriculum. United States: Nelson Thornes Ltd

Neumann, M. M.; \& Neumann, D. L. (2009). For parents particularly: More than just storybooks: Promoting emergent literacy skills in the home. Childhood Education, 85(4), 257-259.

Neumann, M. M., Hood, M., \& Ford, R. M. (2013). Using environmental print to enhance emergent literacy and print motivation. Reading and Writing, 26(5), 23.

Neumann, M. M., Hood, M., \& Neumann, D. L. (2009). The scaffolding of emergent literacy skills in the home environment: A case study. Early Childhood Education Journal, 36(4), 313319. doi: 10.1007/s10643-008-0291-y

Neumann, M. M., Hood, M., Ford, R. M., \& Neumann, D. L. (2012). The role of environmental print in emergent literacy. Journal of Early Childhood Literacy, 12(3), 231-258. doi: $\underline{10.1177 / 1468798411417080}$

Newland, L. A., Gapp, S. C., Jacobs, G. M., Reisetter, M. F., Syed, D. C., \& Wu, C.H. (2011). Mothers' beliefs and involvement: Links with preschool literacy development. International Journal of Psychology: A Biopsychological Approach, 9, 67-90.

Powers, S. J., Wang, Y., Beach, S. D., Sideridis, G. D., \& Gaab, N. (2016). Examining the relationship between home literacy environment and neural correlates of phonological processing in beginning readers with and without a familial risk for dyslexia: an fMRI study. Annals of Dyslexia, 66(3), 337360. doi: 10.1007/s11881-016-0134-2

Praptiningrum, N., \& Purwandari. (2009). Metode multisensori untuk mengembangkan kemampuan membaca anak disleksia di SD inklusi. Jurnal Penelitian Ilmu Pendidikan, 2(2), 179-193.

Reyes, L.; \& Torres, V. (2007). Decolonizing family literacy in a culture circle: Reinventing the family literacy educator's role. Journal of Early Childhood Literacy, 7(1), 73-94.

Roskos, K. A., Christie, J. F., Widman, S., \& Holding, A. (2010). Three decades in: Priming for meta-analysis in playliteracy research. Journal of Early Childhood Literacy, 10(1), 55-96. doi: $\underline{10.1177 / 1468798409357580 .}$.

Ruhaena, L. (2008). Pengaruh metode pembelajaran Jolly Phonics terhadap kemampuan baca-tulis permulaan Bahasa Indonesia dan Bahasa Inggris pada anak prasekolah. Jurnal Penelitian Humaniora, 9(2), 190-204.

Ruhaena, L. (2015). Model multisensori: Solusi stimulasi literasi anak prasekolah. Jurnal Psikologi, 42(1), 47 60. doi: 10.22146/jpsi.6942

Santrock, J. W. (2017). Psikologi pendidikan (Jilid 1) (5 ed.). (H. Bhimasena, Trans.) Jakarta: Salemba Humanika.

Sejati, A. W., \& Yumpi-R, F. (2016). Pengaruh metode multisensori 
terhadap kemampuan mengingat huruf alfabet pada siswa kelompok bermain di Sekolah Cahaya Nurani Jember. INSIGHT, 12(2), 21-38.

Silvers, P., Shorey, M., \& Crafton, L. (2010). Critical literacy in a primary multiliteracies classroom: The hurricane group. Journal of Early Childhood Literacy, 10(4), 379-409. doi: $\underline{10.1177 / 1468798410382354}$

Stephenson, K. A., Parrila, R. K., Georgiou, G. K., \& Kirby, J. R. (2008). Effects of home literacy, parents' beliefs, and children's task-focused behavior on emergent literacy and word reading skills. Scientific Studies of Reading, 12(1), 24-50.

Van der Schuit, M., Peeters, M., Segers, E., van Balkom, H., \& Verhoeven, L. (2009). Home literacy environment of pre-school children with intellectual disabilities. Journal of Intellectual Disability Research, 53(12), 1024-1037. doi: 10.1111/j.1365-2788.2009.01222.x

van Steensel, R., McElvaney, N., Kurvers, J., \& Herppich, S. (2011). How effective are family literacy programs? Result of a meta-analysis. Review of Educational Research, 81(11), 69-96.

Weigel, D. J., Martin, S. S., \& Bennett, K. K. (2010). Pathways to literacy: Connections between family assets and preschool children's emergent literacy skills. Journal of Early Childhood Research, 8(1), 5-22. doi: $\underline{10.1177 / 1476718 \times 09345518}$

Zygouris-coe, V., \& Ph, D. (2007). Family literacy: The missing link to schoolwide literacy efforts. Family Literacy, 48(1), 57-70. 